\title{
Replacing fish meal with alternative protein sources in common carp's feed
}

\author{
Abidemi Adekoya, Maridell Porcadilla, Dániel Varga*, Balázs Kucska
}

Kaposvár University, Faculty of Agricultural and Environmental Sciences,

H-7400 Kaposvár, Guba S. u. 40.

\begin{abstract}
The objective of this study was to investigate the effect of PL68 and soybean meal as alternative protein sources in the diet of common carp (Cyprinus carpio L.). The experiment lasted for four weeks. There was a significant difference $(p<0.05)$ in the final weight and HSI between treatments. There were no significant differences for feed conversion ratio, specific growth rate, condition factor, and fillet weight between groups. The flesh color parameters, $\mathrm{pH}$ values and water losses (dripping loss, thawing loss, and cooking loss) did not show any significant differences between the three dietary treatments. In conclusion the result of this study showed that PL68 and soybean meal can partially replace fishmeal in common carp's diet without any adverse effect on growth but further research is needed to evaluate the effect of different inclusion levels of PL68.
\end{abstract}

Keywords: fish meal replacement, soybean, PL68, common carp

\section{INTRODUCTION}

Aquaculture is the fastest growing sector of the world's food trade, increasing by more than $10 \%$ per year. Fish flesh is highly nutritive and is a rich source of animal proteins. For the improvement of fisheries and to achieve maximum yields from resources of fresh water, it is necessary to provide artificial feed, by which fish grow rapidly and attains maximum weight with shortest possible time (Kushwaha, 2013). Aquaculture production is growing up to satisfy the increasing demand of fish for human consumption (Magalhães et al., 2015) and generally, the feed cost in aquaculture accounts to $40-60 \%$ of total production cost within which the crude protein source being the highest (Cheng et al., 2003). In fish, however, protein is the most important nutrient, fish meal is an adequate and expensive protein source for fish diet and supplementing with other proper protein source would help to reduce total production cost, although supplementing is dependent e.g. on lysine content. Thus, the search for fish meal substitutes and alternative dietary protein sources is an international research priority (Yuan et al., 2010).

Plant proteins has been alternative protein source for fish feed, however, some factors limit the use of plant protein such as its low protein content, high

\footnotetext{
*CORRESPONDING AUTHOR

Kaposvár University, Faculty of Agricultural and Environmental Sciences

$\triangle$ H-7400 Kaposvár, Guba S. str. 40., 正 +36-82-505-800

E-mail:varga.daniel@ke.hu
} 
fiber content, an amino acid imbalance, poor palatability and the presence of anti-nutritional factors (Tibbetts et al., 2006).

Recently some studies were focused on the alternative (vegetable) protein sources in fish feeds. The most important protein sources were bean (Bosnyákné et al. 2018) DDGS (Révész 2016) and soybean Yusuf et al 2016; Solomon et al. 2017).

The aim of the study was to determine the influence of different protein sources (fish meal, PL68, soybean meal) on growth performance and meat quality of common carp (Cyprinus carpio).

\section{MATERIAL AND METHODS}

The trial was carried out at the Aquaculture Department of Kaposvár University. Three iso-nitrogenous and iso-caloric diets were formulated using different protein sources: A - fish meal, B - PL68 (a dried, killed, non-GMO bacterial biomass by-product of the monosodium L-glutamic acid production), $\mathrm{C}$ - soybean meal). The compositions of the diets are shown in Table 1.

\section{Table 1}

Composition of Experimental Diets (\% Dry Matter)

\begin{tabular}{llll}
\hline Ingredients & \multicolumn{2}{l}{ Experimental Diets } & \\
& Diet A & Diet B & Diet C \\
\hline Fish meal & 33.00 & 18.01 & 23.38 \\
Wheat flour & 63.10 & 64.06 & 53.13 \\
Soybean meal & - & - & 19.13 \\
PL68 & - & 14.01 & - \\
Fish oil & 2.80 & 2.80 & 3.19 \\
Vitamin and Mineral premix & 0.10 & 0.10 & 0.11 \\
\hline
\end{tabular}

Common carp $(143.54 \pm 23.57 \mathrm{~g})$ were randomly chosen from a bulk which had been fed on a commercial diet for 10 weeks prior to the experiment. The fish were distributed to 9 small tanks ( 6 individuals/tank). Re-circulated water flowed in each tank and oxygen was also supplied continuously. Water temperature was constantly monitored at $24-26^{\circ} \mathrm{C}$ while oxygen was at $6-7.2$ $\mathrm{mg} / \mathrm{l}$. Fish were fed twice daily until satiation. The experimental period was 4 weeks.

Body weights and lengths were recorded during the trial. Feed intake was measured and recorded every day for 4 weeks period. Two fish per tank were randomly selected for slaughter at the end of the trial. The chosen fish were slaughtered by a blow to the head. Specific growth rate (SGR), feed conversion ratio, slaughter value, condition factor (CF), viscerasomatic index (VSI), and 
hepatosomatic index (HSI) were determined. Body weights were measured and filleted for the meat quality determination. Flesh quality investigations were carried out according to Varga et al (2013).

One-way ANOVA (followed by Tukey Post Hoc test) was used to analyze the effect of different diets on $r$ growth and feed utilization, slaughter value and meat quality parameters of common carp (SPSS for Windows 14.0).

\section{RESULTS AND DISCUSSION}

The results of growth performance are presented in Table 2. There was no significant difference between the groups in the feed consumption.

There was significant difference in final weight (Table 2), fish fed with diet $\mathrm{C}$ had higher weight than diet $\mathrm{B}$, and this might be as a result of high feed consumption of diet C. Also, soybean meal serves as a good protein source for herbivorous fish. Bhilave et al., (2010) reported that the inclusion of $100 \%$ soybean meal in the diet of grass carp (Ctenopharingodon idella) had highest body weight compared to $100 \%$ groundnut cake meal, but the growth was attributed to the higher protein content of the soybean meal.

\section{Table 2}

Growth parameters and somatic indices of the carp fed different feeds

\begin{tabular}{lllll}
\hline & Diet A & Diet B & Diet C & P \\
\hline Feed Intake (g) & $646.67 \pm 114.16$ & $555 \pm 49.52$ & $693.67 \pm 84.85$ & NS \\
Total Initial Weight & $892 \pm 10.15$ & $863.33 \pm 11.02$ & $895 \pm 22.52$ & NS \\
Total Final Weight & $1143.3 \pm 60.08 \mathrm{ab}$ & $1060 \pm 46.77 \mathrm{~b}$ & $1194.67 \pm 7.77 \mathrm{a}$ & $<0.05$ \\
FCR & $2.58 \pm 0.08$ & $2.89 \pm 0.41$ & $2.33 \pm 0.34$ & NS \\
SGR & $0.88 \pm 0.15$ & $0.73 \pm 0.16$ & $1.03 \pm 0.11$ & NS \\
CF & $3.44 \pm 0.06$ & $3.32 \pm 0.11$ & $3.30 \pm 0.08$ & NS \\
\hline
\end{tabular}

The FCR values showed no significant differences between treatments but can be considered to be high in general. Our results are similar to the FCR recorded by Bhilave et. al., (2010) for grass carp (Ctenopharengedon idella) diets containing $50 \%$ soybean.

There was no significant treatment effect in SGR in this experiment (Table 2). A similar result was observed in a study where common carp was fed with fish meal diet and had a significant higher weight compared to common carp fed with sunflower meal, but the difference was not significant (Ali et al., 2016). The lack of treatment effect observed in this study might be due to the short experimental period and small number of fish used in this experiment, and with a longer feeding trial and with a larger number of fish more reliable conclusions could be drawn (Khan et. al., 2003). 
Condition factor (CF) is the basis for the good health condition of the fish (Ighwella et. al, 2014). There was no significant difference for the condition factor in this experiment. Values of $3.44 \pm 0.06,3.32 \pm 0.11$ and $3.30 \pm 0.08$ were calculated for fish fed diets A, B and C, respectively, which shows they were in good condition throughout the experimental period. The result in this experiment is similar to the results of a study using fishmeal and earthworm as a protein source in the diet of common carp with condition factor ranging from $3.19 \pm 0.05$ to $3.22 \pm 0.13$ (Ngoc et.al, 2016).

Results of flesh quality investigations are shown in Table 3. There were no significant effects of diets on the measured parameters.

The ability of the fish meat to retain water was tested on different methods post mortem $24 \mathrm{~h}$ and after 1 week of freezing: dripping, thawing and cooking loss were measured. Fish fed control diet (Diet A) exhibited the least loss of water during cooking followed by Diet $\mathrm{C}$ and $\mathrm{B}$. The trend is the same for the dripping loss post mortem 24 hours and thawing after a week. The three different dietary diets exhibited almost similar losses, without significant differences. The same result with no significant difference were found between treatments for the $\mathrm{pH}$ values of the meat post mortem 24 hours.

\section{Table 3}

Fillet quality parameters of the carp fed different feeds

\begin{tabular}{llll} 
& \multicolumn{2}{l}{ Dietary Treatment (mean \pm SD) } \\
& Diet A & Diet B & Diet C \\
\hline Fillet yield (\%) & $38.05 \pm 2.12$ & $38.01 \pm 2.41$ & $39.99 \pm 4.18$ \\
$\mathrm{~L}^{*}$ & $41.11 \pm 2.02$ & $40.35 \pm 2.03$ & $39.97 \pm 1.77$ \\
$\mathrm{a}^{*}$ & $26.45 \pm 1.71$ & $25.45 \pm 1.40$ & $25.47 \pm 1.50$ \\
$\mathrm{~b}^{*}$ & $21.53 \pm 1.40$ & $20.75 \pm 1.36$ & $20.73 \pm 1.28$ \\
Cooking loss (\%) & $17.02 \pm 1.19$ & $18.49 \pm 1.86$ & $18.21 \pm 2.25$ \\
Dripping loss (\%) & $5.84 \pm 1.46$ & $6.16 \pm 0.98$ & $5.84 \pm 1.37$ \\
Thawing loss (\%) & $7.75 \pm 1.49$ & $8.75 \pm 2.27$ & $8.09 \pm 2.19$ \\
pH & $6.37 \pm 0.13$ & $6.37 \pm 0.18$ & $6.47 \pm 0.25$ \\
\hline
\end{tabular}

Color is one of the most important indicators of flesh quality. No significant differences were observed in the fillet lightness, redness and yellowness. The three protein sources tested in this study did not differ in flesh color quality of common carp. Thus, supplemental replacement of fishmeal with PL68 and soybean ingredients is possible, since flesh color was almost similar to the fish meal fed fish. Another type of bacterial protein that replaced the dietary fish 
meal showed positive effects on the sensory quality of chicken meat after frozen storage due to effects on fatty acid composition but had minimal effects when replaced to soybean meal (Schøyen et al., 2007).

Flesh pH is correlated to the fish texture. Several species show lower fish fillet quality when $\mathrm{pH}$ decreases (Rahmanifarah, et al., 2011). The decrease on the denaturation of the sarcoplasmic proteins reduces the water holding capacity of the meat (Periago et al., 2005). In this experiment, the means of $\mathrm{pH}$ for all the dietary treatments post mortem 24 hours were lower than the previously observed on carp (Cyprinus carpio) and other species like European sea bass (Dicentrarchus labrax), goldfish (Carassius auratus) and several salmonid species which pH ranged from 7.0 to 7.63 (Wilkinson, et al., 2008). Several factors may influence the lower $\mathrm{pH}$ detected on the flesh of the common carp in this study such as the time lag on filleting the fish, and the decomposition of glycogen which increases the lactic acid during or immediately after slaughter (Rahmanifarah et al., 2011). However, the $\mathrm{pH}$ observed in this study remained stable with different dietary treatments and was in line with the experiment conducted by Varga et al., (2013).

\section{CONCLUSIONS}

In this study we show that the, PL68 and soybean meal are effective alternative for partial replacement to fish meal as long as it meets the minimum protein requirements to attain a consumer preferred flesh meat quality, although PL68 was not comparable to soybean meal in terms of growth. The meat quality of the fish fed on three different diets is comparable to each other, thus it can be recommended that PL68 and soybean with inclusion levels of approximately $14 \%$ and $19 \%$ respectively can be used to replace fish meal in the diet and still attain same flesh quality as the fish fed with $100 \%$ fish meal.

Due to short period of time of experiments of this study, the significant effects of the different dietary protein ingredients on flesh quality and growth performance were not fully observed, thus it is recommended that a further study should be done to observe the effect of different inclusion rates on growth performance, ensuring the optimal period of feeding in order to show the best result for flesh quality of common carp.

\section{ACKNOWLEDGEMENTS}

The study was supported by the project GINOP-2.3.4-15-2016-00005.

\section{REFERENCES}


Ali, T., Martınez, S., Monino, A., Tomas-Vidal, A. (2016): Effects of weekly feeding frequency and previous ration restriction on the compensatory growth and body composition of Nile tilapia fingerlings. Egyptian Journal of Aquatic Research, 42: 357-363. DOI: 10.1016/i.ejar.2016.06.004

Bhilave, M.P., Bhosale, S. V., Nadaf, S.B. 2010. Growth response and feed conversion ratio of Ctenopharengedon idella fed on soyabean formulated feed. Biological Forum, 2(1): 67-69.

Bosnyákné Egri H., Keszthelyi S., Varga D., Kucska, B. (2018): Bab felhasználása a pontytakarmányozásban (előzetes eredmények). Acta Agraria Kaposvariensis 22: 1-8. DOI: 10.31914/aak.2256

Cheng, Z.J., Hardy, R.W., Usry, J.L. (2003): Effects of lysine supplementation in plant protein-based diets on the performance of rainbow trout (Oncorhynchus mykiss) and apparent digestibility coefficients of nutrients. Aquaculture, 215: 255-265. DOI: 10.1016/s0044-8486(02)00166-7

Ighwela, K. A., Ahmad, A. Bin, \&Abol-Munafi, A. B. (2014): The selection of viscerosomatic and hepatosomatic indices for the measurement and analysis of Oreochromis niloticus condition fed with varying dietary maltose levels. International Journal of Fauna and Biological Studies IJFBS, 1(13): 1820.

Jobling, M. (1983). Growth studies with fish-overcoming the problems of size variation. J. Fish Biol, 22: 153-157. DOI: 10.1111/j.1095-8649.1983.tb04735.x

Khan, M., Parveen, M., Rab, A., Afzal, M., Sahar, L., Ali, M., Naqvi, S. (2003). Effect of replacement of fish meal by soybean and sunflower meal in the diet of (Cyprinus carpio) fingerlings. Pakistan Journal of Biological Sciences, 6(6): 601-604. DOI: 10.3923/pjbs.2003.601.604

Kushwaha, M.P. (2013): Replacement of fish meal by soybean (Glycine max) in the formulation of fish feed ingredients essential for immunostimulation and growth performance of carps. International Journal of Fauna and Biological Studies, 1(2): 35-38.

Magalhães, R., Coutinho, F., Pousao-Ferreira, P., Aires, T., Oliva-Teles, A., Peres, H. (2015): Corn distiller's dried grains with solubles: Apparent digestibility and digestive enzymes activities in European seabass (Dicentrarchus labrax) and meagre (Argyrosomus regius). Aquaculture, 443: 90-97. DOI: 10.1016/j.aquaculture.2015.03.016

Ngoc, T.N., Pucher, J., Becker, K., Focken, U. (2015): Earthworm powder as an alternative protein source in diets for common carp (Cyprinus carpio L.). Aquaculture Research, 47(9): 2917-2927. DOI: $\underline{10.1111 / \text { are } 12743}$

Rahmanifarah, K., Shabanpour, B., Sattari, A. (2011): Effects of clove oil on Behavior and Flesh quality of common carp (Cyprinus carpio L.) in comparison with Pre-slaughter CO2 stunning, chilling and asphyxia. Turkish Journal of Fisheries and Aquatic Sciences, 11(1): 141-150.

Révész N., Shivendra K., Bogevik, A.S., Shahi, N., Fazekas Gy., Jeney Zs., Jakabné Sándor Zs. (2016): A DDGS emészthetőségének vizsgálata ponty ivadékok két különböző hőmérsékleten történt takarmányozása során. XL. Halászati Tudományos Tanácskozás, p. 11

Schøyen, H., Svihus, B., Storebakken, T., Skrede, A. (2007): Bacterial protein meal produced on natural gas replacing soybean meal or fish meal in broiler chicken diets. Archives of Animal Nutrition, 61(4): 271-279. DOI: $10.1080 / 17450390701431953$

Solomon S.G., Okomoda V.T., Oguche 0. (2017): Nutritional value of raw Canavalia ensiformis and its utilization as partial replacement for soybean meal in the diet of Clarias gariepinus (Burchell, 1822) fingerlings. Food Science \& Nutrition, 6(1): 207-213. DOI: 10.1002/fsn3.548

Tibbetts, S.M., Milley, J.E., Lall, S.P. (2006): Apparent protein and energy digestibility of common and alternative feed ingredients by Atlantic cod, Gadus morhua (Linnaeus 1758 ). Aquaculture, 261: 1314-1327. DOI: 10.1016/j.aquaculture.2006.08.052

Varga, D., Hancz, C., Horn, P., Molnár, T., \& Szabó, A. (2013): Environmental factors influencing the slaughter value and flesh quality of the common carp in four typical fish farms in Hungary. Acta Alimentaria, 42(4): 495-503. DOI: 10.1556/aalim.42.2013.4.4 
Wilkinson, R. J., Paton, N., \& Porter, M. J. R. (2008). The effects of pre-harvest stress and harvest method on the stress response, rigor onset, muscle $\mathrm{pH}$ and drip loss in barramundi (Lates calcarifer). Aquaculture, 282: 26-32. DOI: 10.1016/j.aquaculture.2008.05.032

Yuan, Y., Gong, S., Yang, H., Lin, Y., Yu, D., Luo, Z. (2010): Apparent digestibility of selected feed ingredients for Chinese sucker, Myxocyprinus asiaticus. Aquaculture, 306: 238-243. DOI: $\underline{10.1016 / j . a q u a c u l t u r e .2010 .05 .017}$

Yusuf, A, Umar, R., Micah, D.A., Akpotu, J.A. (2016): Growth response and feed utilization of Clarias gariepinus juvenile fed graded levels of boiled Senna obtusifolia seeds I. seed meal as a replacement for soybean meal. Journal of Advanced Veterinary and Animal Research 3: 345-352. DOI: $\underline{10.5455 / j a v a r .2016 . c 171}$ 